\title{
Iodine Volatility and pH Control in the AP-600 Reactor
}

Prepared by

C.F. Weber, E.C. Beahm

Oak Ridge National Laboratory

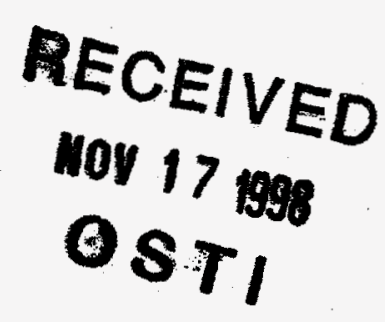

Prepared for

U.S. Nuclear Regulatory Commission

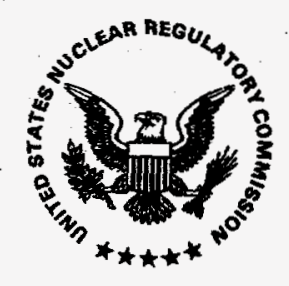




\section{AVAILABILITY NOTICE}

\section{Availability of Reference Materials Cited in NRC Publications}

NRC publications in the NUREG series, NRC regulations, and Title 10, Energy, of the Code of Federal Regulations, may be purchased from one of the following sources:

1. The Superintendent of Documents U.S. Government Printing Office P.O. Box 37082

Washington, DC 20402-9328 <http://www.access.gpo.gov/su_docs> 202-512-1800

2. The National Technical Information Service Springfield, VA 22161-0002 <http://www.ntis.gov/ordernow> $703-487-4650$

The NUREG series comprises.(1) technical and administrative reports, including those prepared for international agreements, (2) brochures, (3) proceedings of conferences and workshops, (4) adjudications and other issuances of the Commission and Atomic Safety and Licensing Boards, and (5) books.

A single copy of each NRC draft report is available free, to the extent of supply, upon written request as follows:

\section{Address: Office of the Chief Information Officer Reproduction and Distribution Services Section \\ U.S. Nuclear Regulatory Commission Washington, DC 20555-0001 \\ E-mail: <GRW1@NRC.GOV>}

Facsimile: 301-415-2289

A portion of NRC regulatory and technical information is available at NRC's World Wide Web site:

$<$ http://www.nrc.gov>

All NRC documents released to the public are available for inspection or copying for a fee, in paper, microfiche, or, in some cases, diskette, from the Public Document Room (PDR):

\author{
NRC Public Document Room \\ 2121 L Street, N.W., Lower Level \\ Washington, DC 20555-0001 \\ <http://www.nrc.gov/NRC/PDR/pdr1.htm> \\ $1-800-397-4209$ or locally $202-634-3273$
}

Microfiche of most NRC documents made publicly available since January 1981 may be found in the Local Public Document Rooms (LPDRs) located in the vicinity of nuclear power plants. The locations of the LPDRs may be obtained from the PDR (see previous paragraph) or through:

\section{<http://www.nrc.gov/NRC/NUREGS/ SR1350/N9/lpdr/html>}

Publicly released documents include, to name a few, NUREG-series reports; Federal Register notices; applicant, licensee, and vendor documents and correspondence; NRC correspondence and internal memoranda; bulletins and information notices; inspection and investigation reports; licensee event reports; and Commission papers and their attachments.

Documents available from public and special technical libraries include all open literature items, such as books, journal articles, and transactions, Federal Register notices, Federal and State legislation, and congressional reports. Such documents as theses, dissertations, foreign reports and translations, and non-NRC conference proceedings may be purchased from their sponsoring organization.

Copies of industry codes and standards used in a substantive manner in the NRC regulatory process are maintained at the NRC Library, Two White Flint North, 11545 Rockville Pike, Rockville, MD 20852-2738. These standards are available in the library for reference use by the public. Codes and standards are usually copyrighted and may be purchased from the originating organization or, if they are American National Standards, from-

$$
\begin{aligned}
& \text { American National Standards Institute } \\
& 11 \text { West } 42 \text { nd Street } \\
& \text { New York, NY } 10036-8002 \\
& \text { <http://www.ansi.org> } \\
& \text { 212-642-4900 }
\end{aligned}
$$

\section{DISCLAIMER}

This report was prepared as an account of work sponsored by an agency of the United States Government. Neither the United States Government nor any agency thereof, nor any of their employees, makes any warranty, expressed or implied, or assumes any legal liability or responsibility for any third party's use, or the results of such use, of any information, apparatus, product, or process disclosed in this report, or represents that its use by such third party would not infringe privately owned rights. 


\section{Iodine Volatility and pH Control in the AP-600 Reactor}

Manuscript Completed: September 1998

Date Published: October 1998

Prepared by

C.F. Weber, E.C. Beahm

Oak Ridge National Laboratory

Managed by Lockheed Martin Energy Research Corp.

Oak Ridge, TN 37831-6285

J.Y. Lee, NRC Project Manager

\section{Prepared for}

Division of Reactor Project Management:

Office of Nuclear Reactor Regulation

U.S. Nuclear Regulatory Commission

Washington, DC 20555-0001

NRC Job Code L1918

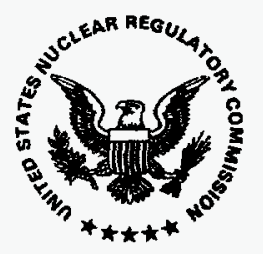




\section{DISCLAIMER}

This report was prepared as an account of work sponsored by an agency of the United States Government. Neither the United States Government nor any agency thereof, nor any of their employees, make any warranty, express or implied, or assumes any legal liability or responsibility for the accuracy, completeness, or usefulness of any information, apparatus, product, or process disclosed, or represents that its use would not infringe privately owned rights. Reference herein to any specific commercial product, process, or service by tracle name, trademark, manufacturer, or otherwise does not necessarily constitute or imply its endorsement, recommendation, or favoring by the United States Government or any agency thereof. The views and opinions of authors expressed herein do not necessarily state or reflect those of the United States Government or any agency thereof. 


\section{DISCLAIMER}

Portions of this document may be illegible in electronic image products. Images are produced from the best available original document. 


\begin{abstract}
Two design-basis accidents for the AP-600 reactor are formulated and evaluated, in which significant bypass of the principal $\mathrm{pH}$ control system occurs. Some iodine released from the reactor primary system is retained in the Incontainment Refueling Water Storage Tank (IRWST) water, never entering the containment, where trisodium phosphate produces a high $\mathrm{pH}$. Some of this iodine is volatilized and is transported into the reactor containment airspace. In the worst case, a small fraction is released to the environment at design-basis leak rate, yielding a total cumulative iodine release at 30 days of $0.0352 \mathrm{~mol}$ $(0.023 \%$ of core iodine inventory) due to the iodine volatilization bypassing the $\mathrm{pH}$ control system. No fission product removal in the containment atmosphere (i.e., natural deposition sprays) is considered.
\end{abstract}





\section{Contents}

Page

Abstract

iii

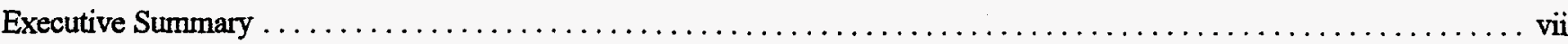

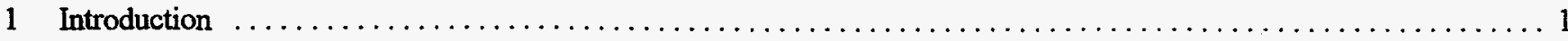

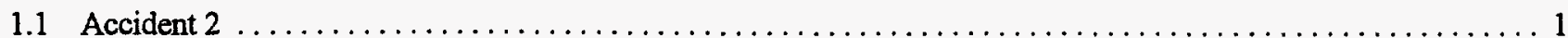

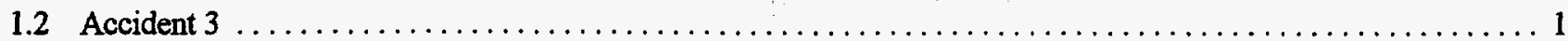

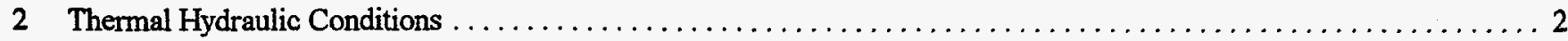

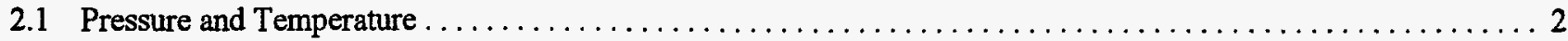

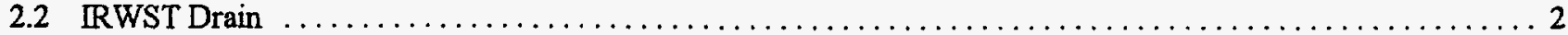

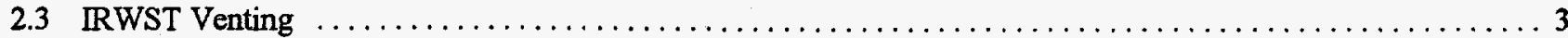

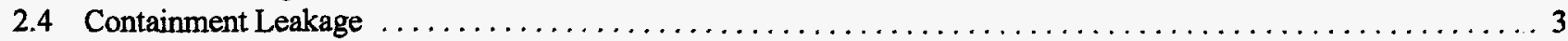

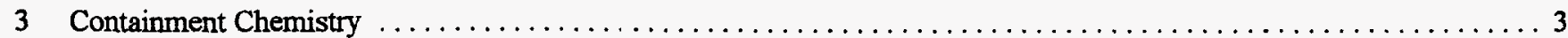

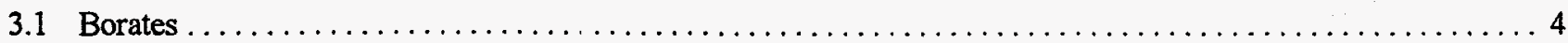

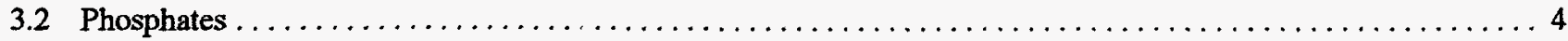

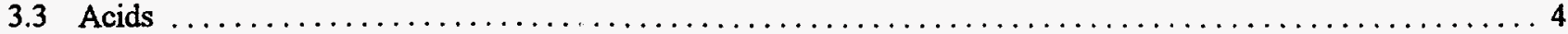

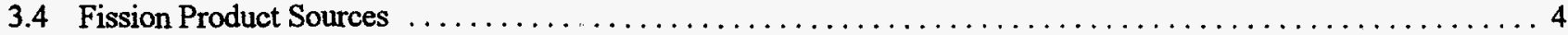

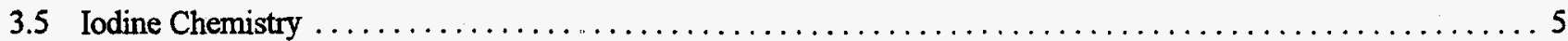

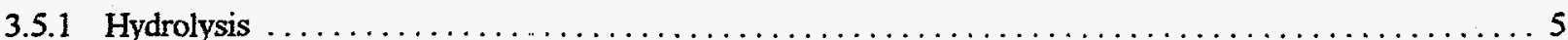

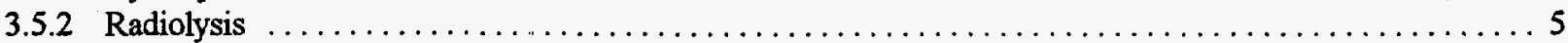

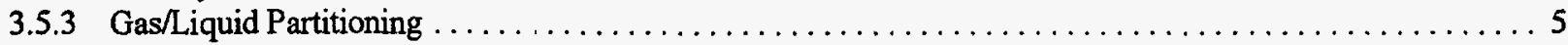

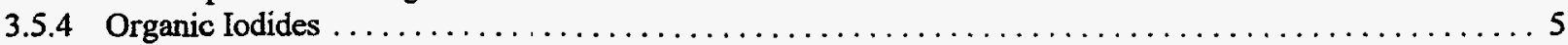

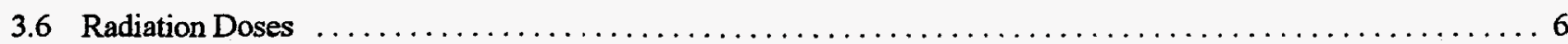

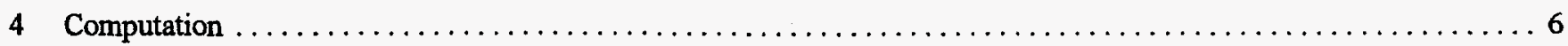

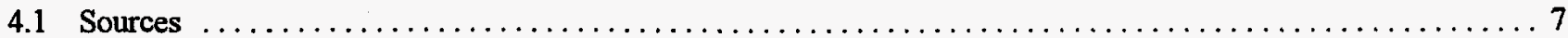

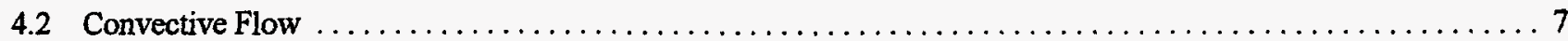

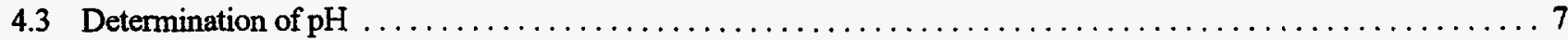

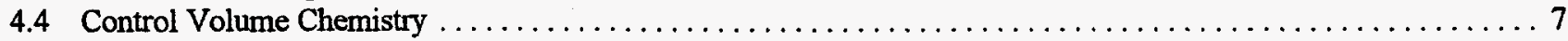

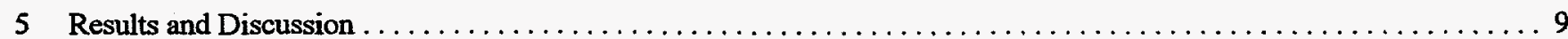

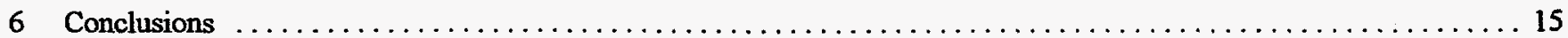

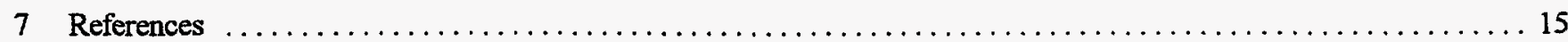

\section{Figures}

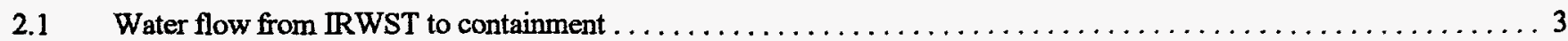

4.1.a Addition of trisodium phosphate (as anhydrous $\mathrm{Na}_{3} \mathrm{PO}_{4}$ ) to containment water $\ldots \ldots \ldots \ldots \ldots \ldots \ldots \ldots$

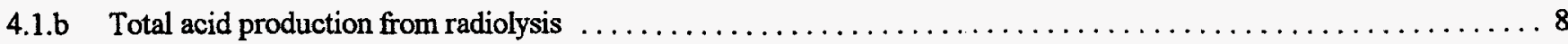




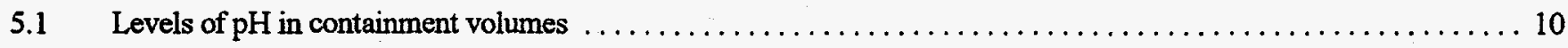

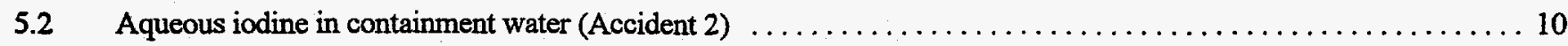

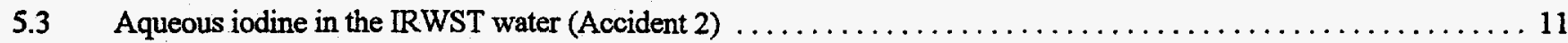

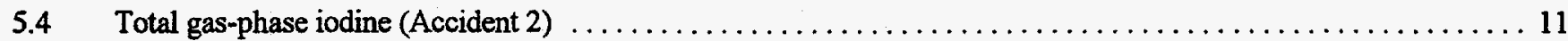

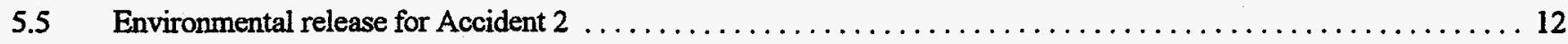

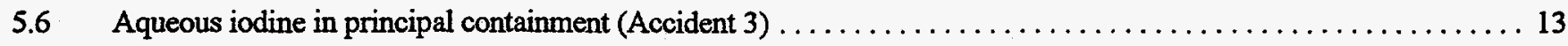

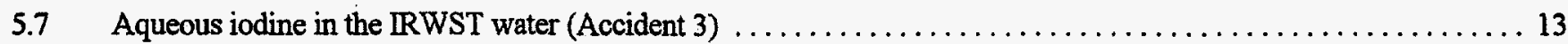

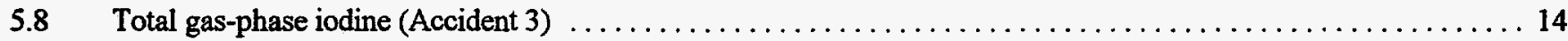

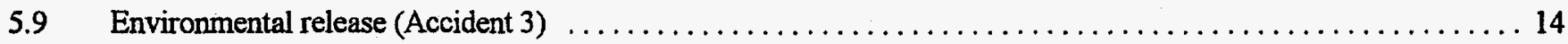

\section{Tables}

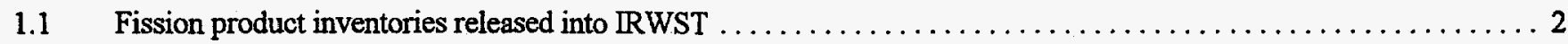

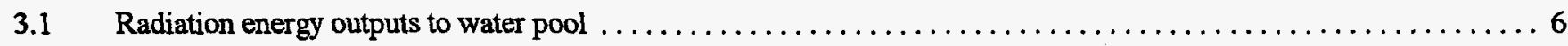

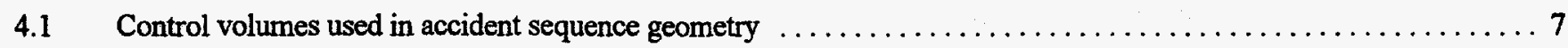

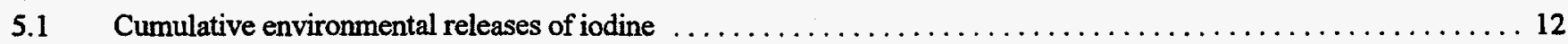




\section{Executive Summary}

Two design-basis accidents for the AP-600 reactor are formulated and evaluated, in which significant bypass of the principal $\mathrm{pH}$ control system occurs. Some iodine released from the reactor primary system is retained in the Incontainment Refueling Water Storage Tank (IRWST) water, never entering the containment, where trisodium phosphate produces a high $\mathrm{pH}$.

This study is a companion to an earlier one, both of which are intended to evaluate $\mathrm{pH}$ control and iodine volatilization in the AP-600 reactor under design basis accident conditions. The previous study considered a variation of the $3 \mathrm{BE}$ (smallbreak LOCA) sequence (hereafter described as "Accident 1"), and was designed to present a maximum challenge to the capabilities of the containment $\mathrm{pH}$ control system.

Accident 2

Accident 2 was originally conceived so as to present the maximum possibility of bypassing the $\mathrm{pH}$ control system.

\section{Accident 3}

Subsequent to the evaluation of Accidents 1 and 2, Westinghouse personnel suggested that even greater bypass of the $\mathrm{pH}$ control system might occur if IRWST drain down began before fission products were deposited. Hence, Accident 3 was conceived by judicious combination of Accidents $I$ and 2 . As in Accident 1 , the fission product source from the primary system is airborne, and assumed to deposit on wetted containment surfaces. As in Accident 2, drainage gutters route the fission products into the IRWST, rather than into the principal containment.

These accident sequences were formulated so as to bypass the $\mathrm{pH}$ control system in the AP- 600 containment. Most iodine is eventually transported to the flooded containment, where trisodium phosphate raises the $\mathrm{pH}$ high enough to prevent volatilization. However, a substantial fraction (about $20 \%$ in Accident 2 and $29 \%$ in Accident 3 ) of the iodine remains in the IRWST, which never fully drains. This water does not access the trisodium phosphate, but instead is the repository for acids produced by radiolysis in containment. The continual lowering of $\mathrm{pH}$ in this volume does lead to some production of $\mathrm{I}_{2}$, which is vented to the containment airspace, and a small amount vented to the atmosphere.

It should be noted that no credit was taken for deposition processes, which may remove some of the gaseous $\mathrm{I}_{2}$. In the IRWST, and to a lesser extent in containment, the condensation of water on walls would both impede permanent deposition and return $\mathrm{I}_{2}$ to the IRWST pool. Here, it would be revolatilized and returned to the containment atmosphere, although the time lag would tend to lower the overall environmental source.

It should also be noted that the temperatures assurned for this sequence $\left(111-120^{\circ} \mathrm{C}\right)$ are beyond the range for which some of the models have been validated. The hydrolysis reactions have been measured at 25,50 , and $90^{\circ} \mathrm{C}$, and extrapolation to slightly higher temperatures is not unreasonable. Data for the radiolysis reactions are sparse at temperatures above $25^{\circ} \mathrm{C}$, and indicate that the model slightly overpredicts conversion to $\mathrm{I}_{2}$ (this is conservative). The chemical equilibrium model is reliable at least to $100^{\circ} \mathrm{C}$, and slight extrapolation should be acceptable. The production of $\mathrm{HCl}$ is more pronounced at higher temperatures, although this effect is not significant below $150^{\circ} \mathrm{C}$. Thus, uncertainties due to temperature extrapolation are not large, and are probably not nearly as great as uncertainties due to sequence formulation.

In the worst case, a small fraction is released to the environment at design-basis leak rate, yielding a total cumulative iodine release at 30 days of $0.0352 \mathrm{~mol}(0.023 \%$ of core iodine inventory) due to the iodine volatilization bypassing the $\mathrm{pH}$ control system. No fission product removal in the containment atmosphere (i.e., sprays) is considered. 


\section{Introduction}

This study is a companion to an earlier one, ${ }^{1}$ both of which are intended to evaluate $\mathrm{pH}$ control and iodine volatilization in the AP-600 reactor under design-basis accident conditions. The previous study considered a variation of the $3 \mathrm{BE}$ (small-break LOCA) sequence (hereafter described as "Acciclent 1") and was designed to present a maximum challenge to the capabilities of the containment $\mathrm{pH}$ control system. Two additional accident sequences are described in the present study.

\subsection{Accident 2}

This accident was originally conceived so as to present the maximum possibility of bypassing the $\mathrm{pH}$ control system. Containment flooding leaves a residual amount (about 20\%) of water in the In-containment Refueling Water Storage Tank (IRWST), where it is not accessible to $\mathrm{pH}$ control chemicals. Typically, under normal operation, containment drainage gutters are set to route all wall condensation (including radiolytically produced acids) into the IRWST, further lowering the $\mathrm{pH}$. Iodine in this water would be subject to volatilization and would be unaffected by the containment $\mathrm{pH}$ control system. The actual accident sequence, designated "Spurious $\mathrm{ADS}$," involves the following features:

(1) Automatic Depressurization System (ADS) Stages 1, 2, and 3 work as intended, but Stage 4 fails.

(2) Injection works for two Core Make-up Tarıss (CMT), two accumulators, the Chemical Volume and Control System (CVS), and the Boric Acid Tank (BAT).

(3) IRWST injection to core fails, but drainage to containment works fully.

(4) IRWST gutter works.

Under this sequence, fission products are deposited directly into the IRWST, where no $\mathrm{pH}$ control occurs. For simplicity, this source is assumed to be instantaneous, composed of the gap releases and in-vessel releases specified in NUREG-1465. ${ }^{2}$ These amounts, which are identical to those used in the earlier study, ${ }^{1}$ are shown in Table 1.1. The sequence begins at this point for purposes of $\mathrm{pH}$ and iodine evaluation. Also at initial time, IRWST drainage to the containment begins and subsequently moves most of the iodine (and other fission products) to the containment. Mixing of the water with trisodium phosphate (TSP) raises the $\mathrm{pH}$ well above 9, virtually eliminating iodine volatilization. However, the residual water in the IRWST contains about $20 \%$ of the iodine released from the primary system; and since no $\mathrm{pH}$ control exists, the potential for iodine volatilization is high.

\subsection{Accident 3}

Subsequent to the evaluation of Accidents 1 and 2, Westinghouse personnel suggested that even greater bypass of the $\mathrm{pH}$ control system might occur if IRWST drain-down began before fission products had been deposited. Hence, Accident 3 was conceived by the judicious combination of Accidents 1 and 2. As in Accident 1, the fission product source from the primary system is airborne and is assumed to deposit on wetted containment surfaces. As in Accident 2, drainage gutters route the fission products into the IRWST, rather than into the principal containment.

In practice, this sequence is modeled similar to Accident 2, except for a source term that is time dependent rather than instantaneous. The timing of fission product release from the primary system is exactly that of Accident 1 , consisting of gap and in-vessel releases from Reference 2. These are deposited directly into the IRWST, simulating the processes of surface deposition and drainage in condensate. While detailed modeling of the actual processes would involve some lag time, it is expected to be short compared with the accident duration. All other thermal hydraulic conditions in Accident 3 are assumed to be identical to those of Accident 2 and are described in the following section. In addition, all additives and chemicals that would affect $\mathrm{pH}$ are also assumed to be identical to those in Accident 2. 
Table 1.1 Fission product inventories released into IRWST

AP-600 Fission product group inventories

\begin{tabular}{|c|c|c|c|c|}
\hline \multirow{2}{*}{\multicolumn{2}{|c|}{$\begin{array}{c}\text { Fission } \\
\text { product } \\
\text { group }\end{array}$}} & \multirow{3}{*}{$\begin{array}{c}\begin{array}{c}\text { Total core } \\
\text { inventory } \\
(\mathrm{g})\end{array} \\
41,1900\end{array}$} & \multicolumn{2}{|c|}{ Released to IRWST } \\
\hline & & & \multirow{2}{*}{$\frac{\text { Fraction }}{1.00}$} & \multirow{2}{*}{$\begin{array}{c}\begin{array}{c}\text { Mass } \\
(\mathrm{g})\end{array} \\
411,900\end{array}$} \\
\hline 1 & $\mathrm{Xe}$ & & & \\
\hline 2 & I & 18,360 & 0.40 & 7,344 \\
\hline 3 & $\mathrm{Cs}$ & 237,600 & 0.30 & 71,280 \\
\hline 4 & $\mathrm{Te}$ & 34,250 & 0.05 & 1,712 \\
\hline 5 & $\mathrm{Sr}$ & 70,700 & 0.02 & 1,414 \\
\hline 6 & Mo & 243,600 & 0.0025 & 609 \\
\hline 7 & $\mathrm{Ba}$ & 107,800 & 0.02 & 2,156 \\
\hline 8 & La & 566,200 & 0,0002 & 113 \\
\hline 9 & $\mathrm{Ce}$ & 200,800 & 0.0005 & 100 \\
\hline 10 & $\mathrm{Sb}$ & 2,037 & 0.05 & 102 \\
\hline 11 & $U$ & $64,360,000$ & 0.0005 & 32,180 \\
\hline 12 & $\mathrm{Ru}$ & 612,000 & 0.0017 & 1,040 \\
\hline
\end{tabular}

¿See Reference 1.

\section{Thermal Hydraulic Conditions}

In the early stages, venting of the primary system to the IRWST would raise its level to a maximum and its temperature to saturation. Continued steaming eventually creates a small, but significant, flow from the IRWST gas space to the main containment. However, this gas flow does not actually begin until the water drainage to main containment is complete (since water drainage itself produces a much larger gas inflow). Containment leakage to the environment represents an additional gas flow.

\subsection{Pressure and Temperature}

According to Westinghouse estimates, the containment pressure will increase to 29 psia within $2 \mathrm{~h}$ of ADS operation (Stages 1 , 2 , and 3) and will decrease to 22 psia after 30 days. Thus, we assume 29 psia for the first $24 \mathrm{~h}$ of the sequence, followed by a linear decrease to 22 psia over the remaining 29 days. Assuming the presence of saturation conditions implies temperatures in all gas and water phases of $120^{\circ} \mathrm{C}$ at the start, decreasing to $111^{\circ} \mathrm{C}$ after 30 days.

\subsection{IRWST Drain}

The flow rate of water from the IRWST to the containment was taken from plots of such flow in the AP-600 design document. ${ }^{4}$ The drain flow, as illustrated in Figure 2.1, takes about $5 \mathrm{~h}$ to complete. 
ORNL DWG 97C-130000

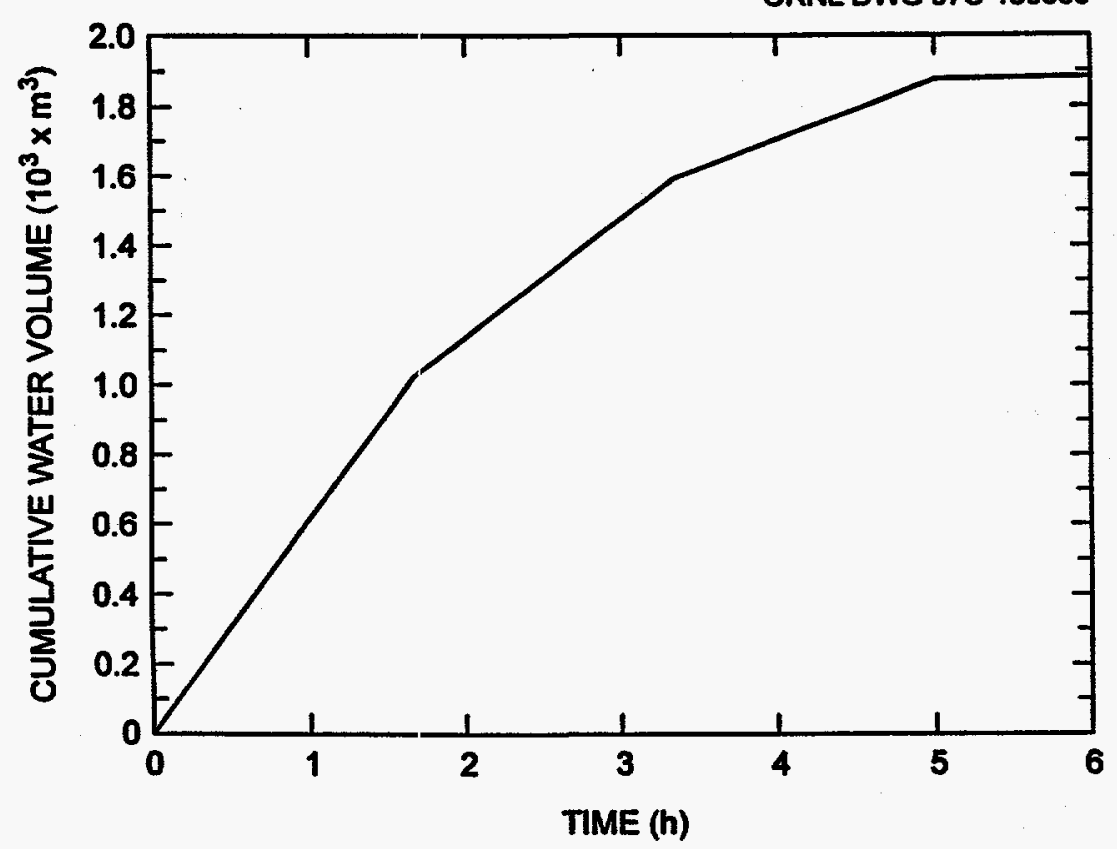

Figure 2.1 Water flow from IRWST to containment

\subsection{IRWST Venting}

As stated in Section 2, steaming of the IRWST produces a small gas flow to containment after the water drain is complete. The steaming is caused by continued heat generation due to decay heat of the fission products, coupled with condensation of steam on the containment shell. Westinghouse provided estimates ${ }^{3}$ of $250 \mathrm{cfm}$ at $2 \mathrm{~h}, 100 \mathrm{cfm}$ at $24 \mathrm{~h}$, and $40 \mathrm{cfm}$ at 6 days. These three values were fit to the empirical form

$$
\text { flow rate }\left(\mathrm{m}^{3} / \mathrm{s}\right)=\mathrm{A}_{0} \exp (\mathrm{At}+\mathrm{B}),
$$

resulting in values of $A=8.54 \times 10^{-6}\left(\mathrm{~s}^{-1}\right), B=2.53 \times 10^{-3}$. The constant $A_{0}=1 \mathrm{~m}^{3} / \mathrm{s}$ allows for changing to other units. The flow in Equation (1) was applied after $5 \mathrm{~h}$ and lasted throughout the entire 30 days, although it became negligibly small by the end of the accident period.

\subsection{Containment Leakage}

Westinghouse provided an estimate that the containment leakage to the atmosphere was $0.12 \%$ per day. Use of this estimate resulted in flow rate of $6.62 \times 10^{-4} \mathrm{~m}^{3} / \mathrm{s}$ throughout each accident sequence.

\section{Containment Chemistry}

Most iodine enters containment as CsI aerosol, ${ }^{5,6}$ which is readily dissolved in sumps or surface condensate. Even if released into the containment atmosphere, most iodine will quickly settle onto wetted surfaces and will be washed into sumps or pools. In accident sequences 2 and 3, CsI is released directly into IRWST water. It has been well established ${ }^{6-8}$ that the volatility of iodine is closely related to the $\mathrm{pH}$ of water pools in various containment volumes. 


\section{Containment Chemistry}

Even highly soluble iodide ( $\left.\mathrm{I}^{-}\right)$can be converted to other forms (e.g., $\mathrm{I}_{2}$ and organic iodides) that more easily evaporate from water and could be subsequently vented to the environment. At $25^{\circ} \mathrm{C}$, this conversion is negligible for $\mathrm{pH}$ levels greater than 7 , but dominant for $\mathrm{pH}$ levels less than 3. Thus, the presence of various chemicals that affect water $\mathrm{pH}$ is quite important in determining the extent of iodine volatility. In each accident sequence, we consider three such chemicals present in the AP-600 (i.e., borates, phosphates, and hydrochloric acid) that are expected to dominate the calculation of $\mathrm{pH}$ in various locations.

\subsection{Borates}

Most water in these sequences originally contains various forms of borates, which, regardless of initial form, hydrolyzes to form boric acid and various polyborate species.' The concentration in the IRWST is $2700 \mathrm{ppm}(0.25 \mathrm{~mol} / \mathrm{L})$ as boron. The concentration in the reactor primary system varies, depending on additions from various tanks and accumulators; however, the average is not significantly different from that of the IRWST. While the processes of steaming and condensation produce surfaces wetted with nonborated water, the latter is expected to quickly drain into pools. Thus, all water is assumed to have a boron concentration of $2700 \mathrm{ppm}(0.25 \mathrm{~mol} / \mathrm{L})$.

\subsection{Phosphates}

The AP-600 design includes the placement of baskets of trisodium phosphate (TSP) in the lower containment, which will dissolve and increase the $\mathrm{pH}$ in the flooded containment. The design specification is for a minimum of $7830 \mathrm{lb}$ of TSP (43\% as anhydrous salt, corresponding to the dodecahydrate $\mathrm{Na}_{3} \mathrm{PO}_{4} \cdot 12 \mathrm{H}_{2} \mathrm{O}$ ), which translates to $9309 \mathrm{~mol}$. Invariably, TSP contains small amounts of $\mathrm{NaOH}$ (true even of reagent-grade TSP); however, this excess caustic was not considered. (It is conservative to neglect the excess $\mathrm{NaOH}$.) In these accident sequences, the TSP begins dissolving when the water level in containment reaches the floor of the steam generator rooms (83-ft elevation) and is completely dissolved after rising $3 \mathrm{~m}(9.8 \mathrm{ft})$ above the floor. It is assumed to be distributed uniformly and instantly throughout all water in the flooded containment (i.e., a well-mixed volume is assumed).

\subsection{Acids}

Irradiation tends to produce various acids that would decrease $\mathrm{pH}$; therefore, their effects must be considered in assessing overall iodine volatility. Small amounts of nitric acid are produced from the irradiation of air-water mixtures; however, this effect is assumed to be negligible and, therefore, was not included in the present analysis. The irradiation and heating of electrical cable insulation have been shown to produce significant quantities of hydrochloric and sulfuric acids, ${ }^{10}$ which are subsequently dissolved in condensate and collected in sumps. In the present sequences, the calculation follows the procedure outlined in Appendix B of Reference 10. Since containment drainage gutters are set to route wall condensation to the IRWST, all acids are deposited there as well.

\subsection{Fission Product Sources}

In Accident 2, all fission products are assumed to be released through spargers into the IRWST at the start of the accident sequence. Because there is very little gas space in the IRWST at this time, noble gases are assumed to vent instantly into the containment atmosphere. All iodine is assumed to be initially CsI and to be immediately dissolved in IRWST water. In reality, a small quantity of volatile iodine might be present in the source from the primary system; however, our goal is to predict volatilization of that iodine which was initially nonvolatile. The assumption that all iodine occurs initially as iodide allows a clearer assessment of this process. Finally, all other fission products are assumed to be nonvolatile for the entire accident. They are released into water and travel with it either in solution or in suspension. The primary reason for considering noble gases and nonvolatile fission products is to allow calculation of the radiation doses to water pools and gas spaces.

For Accident 3, the release is initially into containment airspace, but all fission products except noble gases become quickly entrained in condensate and deposited in the IRWST. This is true of both CsI and less volatile fission products. Noble gases, 
however, are assumed to be instantly released into the containment, as in Accident 2. However, in Accident 3, the releases are timed (see Reference 2), rather than instantaneous.

\subsection{Iodine Chemistry}

\subsubsection{Hydrolysis}

In aqueous solution, iodine can undergo hydrolysis, which is described well by the following reaction set: ${ }^{8,11}$

$$
\begin{aligned}
& \mathrm{I}_{2}+\mathrm{H}_{2} \mathrm{O} \leftrightarrow \mathrm{I}^{-}+\mathrm{HOI}+\mathrm{H}^{+}, \\
& 2 \mathrm{HOI} \leftrightarrow \mathrm{I}^{-}+\mathrm{HIO}_{2}+\mathrm{H}^{+}, \\
& \mathrm{HOI}+\mathrm{HIO}_{2} \leftrightarrow \mathrm{I}^{-}+\mathrm{HIO}_{3}+\mathrm{H}^{+} .
\end{aligned}
$$

The end-point oxidation states that $\mathrm{I}^{-}$and $\mathrm{IO}_{3}^{-}$(or $\mathrm{HIO}_{3}$ ) are both extremely soluble and, therefore, highly desirable. The $\mathrm{HOI}$ and $\mathrm{HIO}_{2}$ species are reaction intermediates, which may be volatile but are regarded as having short lifetimes. However, molecular iodine, $\mathrm{I}_{2}$, is stable and sparingly soluble. It can be seen in the above reactions that low $\mathrm{pH}$ levels (i.e., a large $\mathrm{H}^{+}$ concentration) will result in more $\mathrm{I}_{2}$ and less $\mathrm{I}^{-}$and $\mathrm{IO}_{3}^{-}$. Each forward and reverse reaction gives rise to a single rate equation, as described in Reference 11.

\subsubsection{Radiolysis}

In a radioactive environment, the presence of free radicals induces additional aqueous reactions. The overall result can be described empirically by the equilibrium ${ }^{11}$

$$
\frac{\left[H^{+}\right]^{2}\left[I^{-}\right]^{2}}{\left[I_{2}\right]}=a+b\left[H^{+}\right]
$$

where $a$ and $b$ are known coefficients depending only on temperature. The actual rate equations used in this study are based on the catalytic decomposition of hydrogen peroxide, one of the stable by-products of irradiating water. The peroxide inventory is estimated empirically, based on cumulative dose, $\mathrm{pH}$, dissolved oxygen content, and temperature. The forward rate coefficients are then based on the data of Liebhafsky, ${ }^{12}$ and the reverse coefficients are chosen to move steadily toward equilibrium (3).

\subsubsection{Gas/Liquid Partitioning}

The same equation is used to describe the evaporation of volatile iodine species from water $\left(\mathrm{I}_{2}\right.$ or $\left.\mathrm{CH}_{3} \mathrm{I}\right)$ and their dissolution from gas back to the water. The model is based on the equilibrium partition coefficients (inverse of Henry's Law constant) for each species and rate equations obtained from natural convection correlations. ${ }^{11}$

\subsubsection{Organic Iodides}

Organic iodides are described empirically by the formation of $\mathrm{CH}_{3} \mathrm{I}$ from $\mathrm{I}_{2}$ in the gas phase. The model used is described fully in Reference 11. Analogous to $\mathrm{I}_{2}, \mathrm{CH}_{3} \mathrm{I}$ is sparingly soluble in water - an effect which is negligible in the accident sequences considered here. 


\section{Computation}

\subsection{Radiation Doses}

Several of the models depend on the prediction of decay energy in air or water. Energy outputs for beta and gamma radiation are given in Table 3.1 for each fission product group at various times. These were calculated by using ORIGEN ${ }^{13}$ results for fission product inventories, together with ICRP data ${ }^{14}$ for nuclide decay energies.

The doses to water assume that all energy from beta and gamma decay is absorbed in water. They are calculated by combining information from Table 3.1 (interpolated to the correct time) with the water inventories of each fission product group at each time step, as obtained from MAAP reactor analysis code output.

The rate of $\mathrm{HCl}$ formation in cable sheathing is based on the energy production rates (both beta and gamma) due to fission products that are airborne or deposited on surfaces. The latter rates are calculated using the procedure described in Reference 10.

Table 3.1 Radiation energy outputs to water pool

Beta-energy output by MAAP fission product group $\left[(\mathrm{MeV} / \mathrm{s}) / \mathrm{kg} \times 10^{-12}\right]$

\begin{tabular}{|c|c|c|c|c|c|c|c|c|c|c|c|c|}
\hline $\begin{array}{l}\text { Time } \\
\text { (h) }\end{array}$ & $\begin{array}{r}X e \\
1\end{array}$ & $\begin{array}{r}\text { CsI } \\
2\end{array}$ & $\begin{array}{r}\mathrm{TeO}_{2} \\
3\end{array}$ & $\begin{array}{r}\mathrm{SrO} \\
4\end{array}$ & $\begin{array}{r}\mathrm{MoO}_{2} \\
5\end{array}$ & $\begin{array}{r}\mathrm{CsOH} \\
6\end{array}$ & $\begin{array}{r}\mathrm{BaO} \\
7\end{array}$ & $\begin{array}{r}\mathrm{La}_{2} \mathrm{O}_{3} \\
8\end{array}$ & $\begin{array}{r}\mathrm{CeO}_{2} \\
9\end{array}$ & $\begin{array}{l}\text { Sb } \\
10\end{array}$ & $\begin{array}{c}\mathrm{Te}_{2} \\
11\end{array}$ & $\begin{array}{r}\mathrm{UO}_{2} \\
12\end{array}$ \\
\hline 0 & 12.470 & 230.89 & 134.70 & 38.138 & 10.040 & 34.251 & 69.500 & 57.823 & 8.365 & 650.10 & 168.00 & 0.337 \\
\hline 1 & 5.946 & 185.28 & 53.26 & 35.527 & 4.500 & 17.302 & 29.253 & 34.856 & 8.292 & 232.70 & 66.43 & 0.169 \\
\hline 2 & 4.729 & 152.24 & 29.82 & 33.271 & 4.134 & 9.956 & 19.828 & 30.953 & 8.186 & 141.80 & 37.19 & 0.138 \\
\hline 5 & 3.481 & 109.61 & 15.39 & 28.209 & 3.987 & 4.114 & 11.146 & 25.192 & 7.881 & 87.83 & 19.20 & 0.128 \\
\hline 10 & 2.883 & 88.071 & 11.891 & 23.071 & 3.782 & 1.564 & 8.876 & 19.865 & 7.405 & 56.39 & 14.83 & 0.120 \\
\hline 24 & 2.068 & 61.725 & 8.980 & 16.831 & 3.266 & 0.549 & 8.418 & 14.752 & 6.300 & 31.67 & 11.20 & 0.101 \\
\hline 48 & 1.362 & 41.878 & 7.093 & 13.990 & 2.537 & 0.512 & 7.985 & 13.030 & 5.002 & 24.700 & 8.846 & 0.076 \\
\hline 96 & 0.954 & 24.966 & 4.869 & 13.117 & 1.533 & 0.505 & 7.184 & 11.974 & 3.698 & 17.820 & 6.073 & 0.043 \\
\hline
\end{tabular}

Gamma-energy output by MAAP fission product group $\left[(\mathrm{MeV} / \mathrm{s}) / \mathrm{kg} \times 10^{-12}\right]$

\begin{tabular}{|c|c|c|c|c|c|c|c|c|c|c|c|c|}
\hline $\begin{array}{l}\text { Time } \\
\text { (h) }\end{array}$ & $\begin{array}{r}\mathrm{Xe} \\
1\end{array}$ & $\begin{array}{r}\text { CsI } \\
2\end{array}$ & $\begin{array}{r}\mathrm{TeO}_{2} \\
3\end{array}$ & $\begin{array}{r}\mathrm{SrO} \\
4\end{array}$ & $\begin{array}{r}\mathrm{MoO}_{2} \\
5\end{array}$ & $\begin{array}{r}\mathrm{CsOH} \\
6\end{array}$ & $\begin{array}{r}\mathrm{BaO} \\
7\end{array}$ & $\begin{array}{r}\mathrm{La}_{2} \mathrm{O}_{3} \\
8\end{array}$ & $\begin{array}{r}\mathrm{CeO}_{2} \\
9\end{array}$ & $\begin{array}{l}\mathrm{Sb} \\
10\end{array}$ & $\begin{array}{r}\mathrm{Te}_{2} \\
11\end{array}$ & $\begin{array}{r}\mathrm{UO}_{2} \\
12\end{array}$ \\
\hline 0 & 19.470 & 753.32 & 235.01 & 60.098 & 15.169 & 52.232 & 56.141 & 41.486 & 4.597 & 2253.0 & 293.10 & 0.119 \\
\hline 1 & 8.780 & 615.56 & 97.90 & 49.627 & 2.386 & 21.006 & 10.097 & 27.007 & 4.549 & 793.10 & 122.10 & 0.097 \\
\hline 2 & 6.729 & 500.61 & 54.26 & 41.258 & 1.620 & 9.718 & 7.156 & 22.746 & 4.481 & 466.50 & 67.67 & 0.092 \\
\hline 5 & 4.005 & 347.38 & 25.68 & 24.911 & 1.525 & 4.518 & 6.473 & 17.590 & 4.280 & 270.70 & 32.03 & 0.088 \\
\hline 10 & 2.298 & 278.13 & 21.53 & 12.608 & 1.447 & 3.654 & 6.317 & 15.348 & 3.971 & 161.00 & 26.85 & 0.083 \\
\hline 24 & 1.084 & 199.53 & 17.62 & 3.498 & 1.249 & 3.317 & 6.153 & 14.045 & 3.255 & 77.95 & 21.98 & 0.070 \\
\hline 48 & 0.529 & 144.10 & 12.98 & 0.592 & 0.970 & 3.257 & 5.900 & 13.243 & 2.418 & 59.510 & 16.190 & 0.052 \\
\hline 96 & 0.317 & 91.37 & 7.51 & 0.018 & 0.586 & 3.164 & 5.432 & 12.067 & 1.587 & 44.590 & 9.368 & 0.030 \\
\hline
\end{tabular}

\section{Computation}

The geometry for the sequences in Accidents 2 and 3 involves only the three control volumes listed in Table 4.1. A computational model was constructed to describe each relevant physical and chemical process in the entire system. Rate equations were developed for each process and solved together to give a transient description of convective transport and chemical interactions for the duration of the accident. The sequences are divided into discrete time steps, and at each step the following actions are taken (in the order indicated): (1) sources of fission products or $\mathrm{pH}$-influencing chemicals are introduced; (2) convective flow transfers between different control volumes are computed; (3) the $\mathrm{pH}$ within each control volume is 
Table 4.1 Control volumes used in accident sequence geometry

\begin{tabular}{lcc}
\hline $\begin{array}{c}\text { Control } \\
\text { volume }\end{array}$ & $\begin{array}{c}\text { Total volume } \\
\left(\mathrm{m}^{3}\right)\end{array}$ & $\begin{array}{c}\text { Max. water } \\
\text { volume }\left(\mathrm{m}^{3}\right)\end{array}$ \\
\hline Containment & 47694 & 1862 \\
IRWST & 2425 & 2265 \\
Environment & & \\
\hline
\end{tabular}

calculated; and (4) the speciation, chemical interactions, or phase change within each control volume is calculated. Each subcalculation is discussed in more detail in the subsections that follow.

\subsection{Sources}

In addition to fission products, there are sources of $\mathrm{pH}$-influencing chemicals. Borate is present in all water, as mentioned in Section 3.1. TSP is dissolved during the first few hours, consistent with the water level increase in containment (see Section 3.2). Acid is added as $\mathrm{HCl}$ according to the model in Reference 10. The transient additions used for TSP and $\mathrm{HCl}$ are shown in Figures 4.1.a-4.1.b. (The production of $\mathrm{HCl}$ is due almost entirely to radiation from noble gases, which is the same in each of the sequences considered here.)

\subsection{Convective Flow}

Transfers of gas or liquid inventories between control volumes are based on the flows discussed in Section 2 . The volume fraction of fluid that leaves the control volume during a time step is assumed to carry that same fraction of components. Thus, for a 1-h time step, containment venting to the atmosphere moves $.12 / 24$, or $.005 \%$, of the containment gas volume (see Section 2.4). Then, in the same time step, $.005 \%$ of current gaseous iodine and noble gas inventories would also be transferred to the environment.

\subsection{Determination of $\mathrm{pH}$}

Inventories of all aqueous constituents are updated in the source and flow steps above. The calculation of $\mathrm{pH}$ assumes that equilibrium is reached rapidly. The equilibrium calculation model uses the principal subroutine "GASOL" of the code SOLGASMIX. ${ }^{\text {s }}$ The calculation uses an extended Debye-Hückel form for activity coefficients and includes multiple phosphate and borate species. The model itself and its validation with actual data are described in Reference 11.

\subsection{Control Volume Chemistry}

The most complicated part of the calculation is the simultaneous solution of all rate equations arising in Section 3.5 relative to iodine hydrolysis, radiolysis, gas/iquid partitioning, and methyl iodide formation. This set of ordinary differential equations is solved by using the routine LSODE and related routines. ${ }^{16}$ 


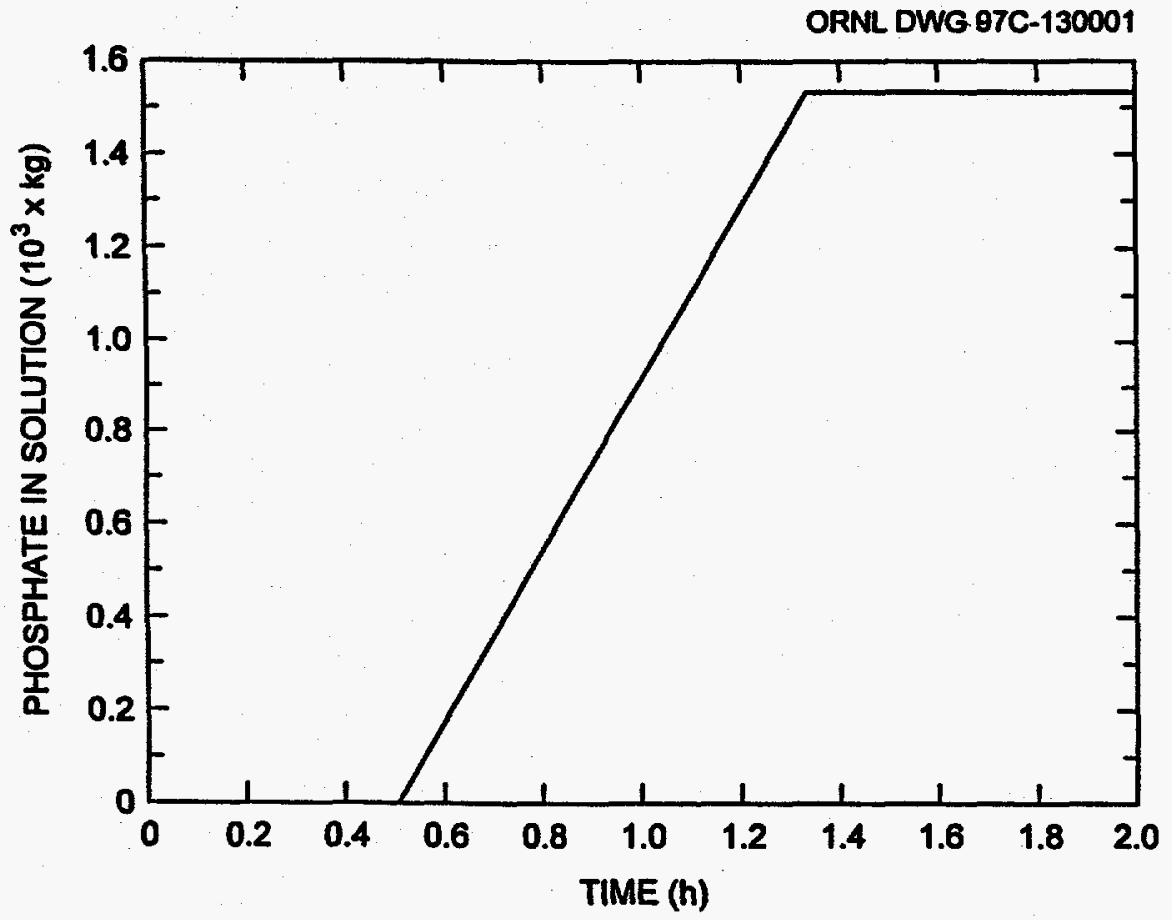

Figure 4.1.a Addition of trisodium phosphate (as anhydrous $\mathrm{Na}_{3} \mathrm{PO}_{4}$ ) to containment water

ORNL DWG 97C-130002

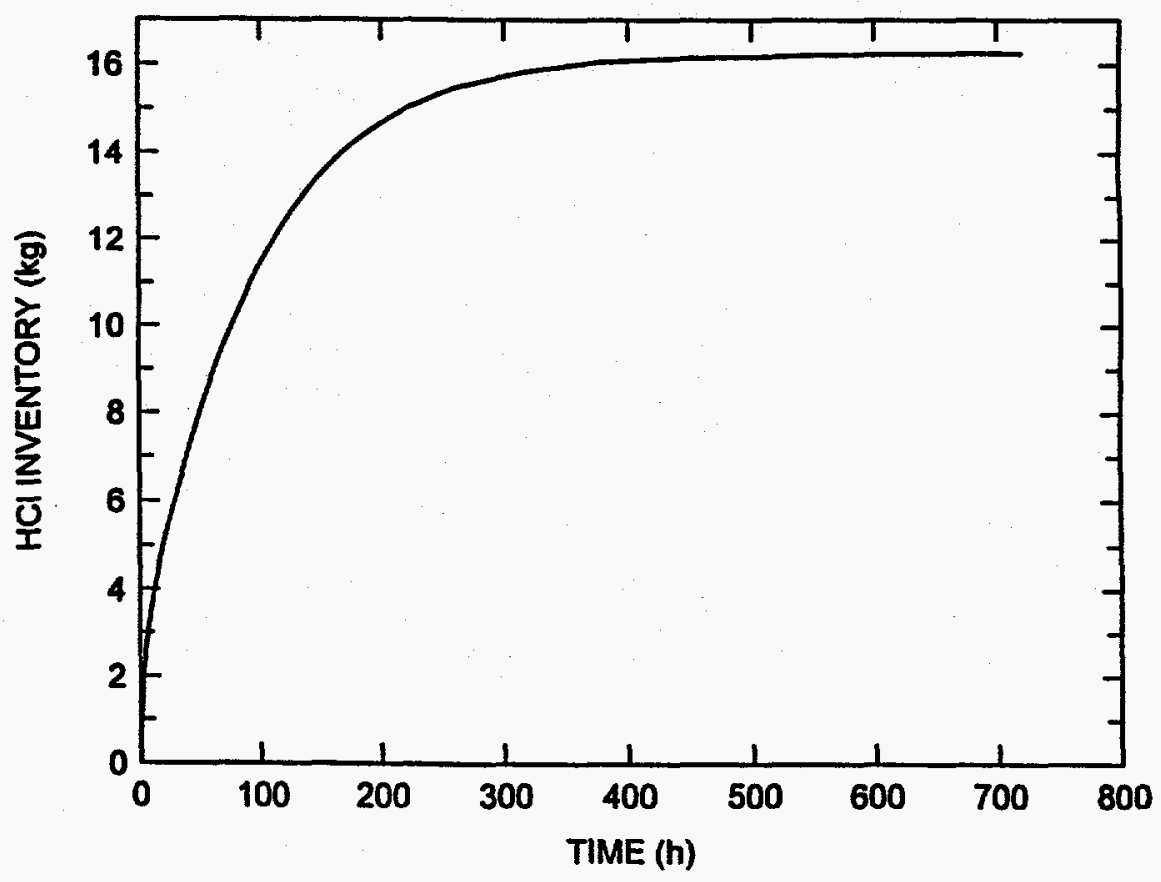

Figure 4.1.b Total acid production from radiolysis 


\section{Results and Discussion}

The model described in Section 4 was run for a 30-day transient in the case of both Accidents 2 and 3 . The pH levels in the IRWST and containment water were virtually identical in each sequence (see Figure 5.1). The $\mathrm{pH}$ of borated water, which is somewhat below 6, is changed considerably by sources of other chemicals (water is above $100^{\circ} \mathrm{C}$ ). Due to the $\mathrm{HCl}$ source, the $\mathrm{pH}$ of the IRWST water declined steadily for the first $8 \mathrm{~h}$ and, after 30 days, had decreased to almost 3.0. While the $\mathrm{pH}$ of the containment water declined briefly, it rose abruptly when phosphate dissolution began and stayed above 9.5 for the remainder of the 30-day transient.

For Accident 2, iodine speciation in the two water pools is depicted in Figures 5.2 and 5.3, which show that a gradual oxidation of $\mathrm{I}^{-}$to $\mathrm{IO}_{3}{ }^{-}$began quickly in each case. Note that the plotted quantity "fraction of containment total" includes all iodine released from the reactor coolant system, which is $40 \%$ of the total core inventory. In the IRWST water, the process continued throughout the 30-day accident transient, eventually yielding almost complete conversion to $\mathrm{IO}_{3}{ }^{-}$. This is consistent with experimental results at $25^{\circ} \mathrm{C}$ and is caused by the tandem processes of radiolysis and hydrolysis. In the former, $\mathrm{I}^{-}$is converted to $I_{2}$; in the latter, $\mathrm{I}_{2}$ is converted-primarily to $\mathrm{I}^{-}$, but also some fraction to $\mathrm{IO}_{3}^{-}$. Over time, accumulation of $\mathrm{IO}_{3}{ }^{-}$is the inevitable result for moderate $\mathrm{pH}$ values. However, in the containment sump, the process was abruptly terminated once the water level rose sufficiently to dissolve TSP (at about $30 \mathrm{~min}$ ). At this point, the inventories of $\mathrm{I}_{2}$ and HOI decreased drastically, and the destruction of $\mathrm{I}^{-}$was effectively ended. In Figure 5.2, inventories of all species increased due to additions from IRWST drainage; however, they stabilized at about $5 \mathrm{~h}$ and changed very little after that point. The intermediates HOI and $\mathrm{HIO}_{2}$ continued to oxidize slowly, and the inventory of $\mathrm{IO}_{3}^{-}$eventually exceeded that of $\mathrm{HIO}_{2}$ (at about 17 days). Note also that the $\mathrm{I}_{2}$ concentration was much higher in the IRWST water (where the $\mathrm{pH}$ was low). While complete oxidation to $\mathrm{IO}_{3}{ }^{-}$would occur in a closed volume, the presence of a significant aqueous $I_{2}$ inventory in a vented control volume would allow evaporation and escape of gaseous $I_{2}$. This effect can be seen in Figure 5.4, where $I_{2}$ has evaporated from the IRWST water into the IRWST airspace and is subsequently vented into the containment airspace. From there, some $I_{2}$ is redissolved in the containment water (see Section 3.5.3), while a small amount is actually released to the environment.

The cumulative environmental releases at various times are shown in Table 5.1. The molar amounts are direct output of the calculations. At each time step, the rate of activity released is calculated by

$$
\dot{Q}_{\mathrm{I}}=\mathrm{P}_{\mathrm{i}} \dot{\mathrm{n}}_{\mathrm{I}} \text {, }
$$

where $\dot{Q}_{I}$ is the rate of activity release during time step $I, \dot{n}_{I}=$ total iodine leak rate $(\mathrm{mol} / \mathrm{s})$ at step $I$, and $P_{i}=P\left(t_{i}\right)[\mathrm{Ci} / \mathrm{mol}$ total $\Pi$ is determined from ORIGEN calculations at various time steps. A good approximation for the AP-600 is

$$
\ln (\mathrm{P})= \begin{cases}-3.5089-0.09885 \mathrm{t}+0.002420 \mathrm{t}^{2} & 0<\mathrm{t}<24 \\ -4.4876-0.01424 \mathrm{t}+0.000013 \mathrm{t}^{2} & 24<\mathrm{t}<720\end{cases}
$$

where $t$ is in hours. The cumulative activity is, then,

$$
\mathrm{Q}=\int \dot{\mathrm{Q}}\left(\mathrm{t}^{\prime}\right) \mathrm{dt^{ \prime }}=\sum \dot{\mathrm{Q}}_{\mathrm{I}} \Delta \mathrm{t}_{\mathrm{i}} \text {. }
$$

The speciation of volatile gaseous iodine, as shown in Figure 5.5, confirms that $\mathrm{I}_{2}$ is the dominant form, as expected.

The iodine inventories for Accident 3 (see Figures 5.6-5.9) are very similar to the analogous results for Accident 2. Since almost 50\% more iodine ends up in the IRWST water, greater volatilization would be expected. This is borne out in Table 5.1, where roughly $50 \%$ more iodine is released to the environment at times exceeding $24 \mathrm{~h}$. 
Results and Discussion

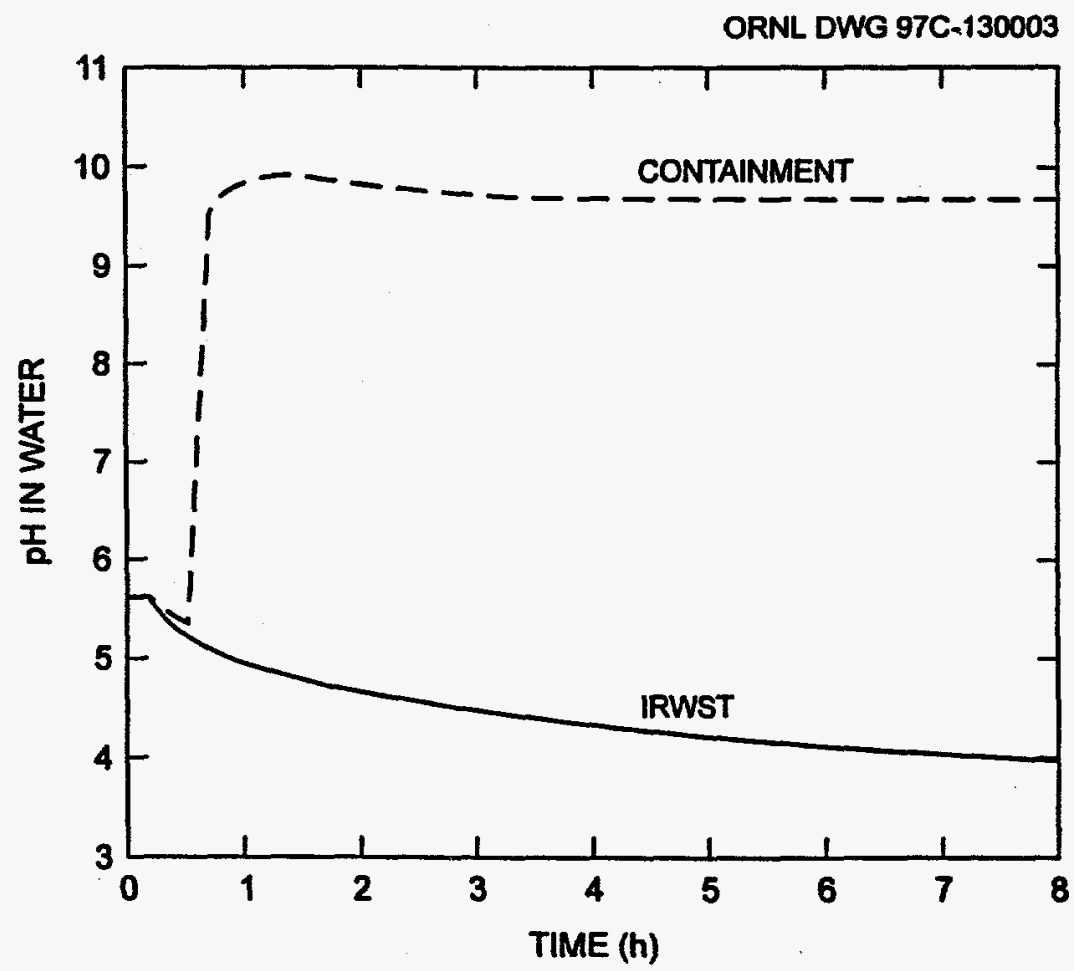

Figure 5.1 Levels of $\mathrm{pH}$ in containment volumes

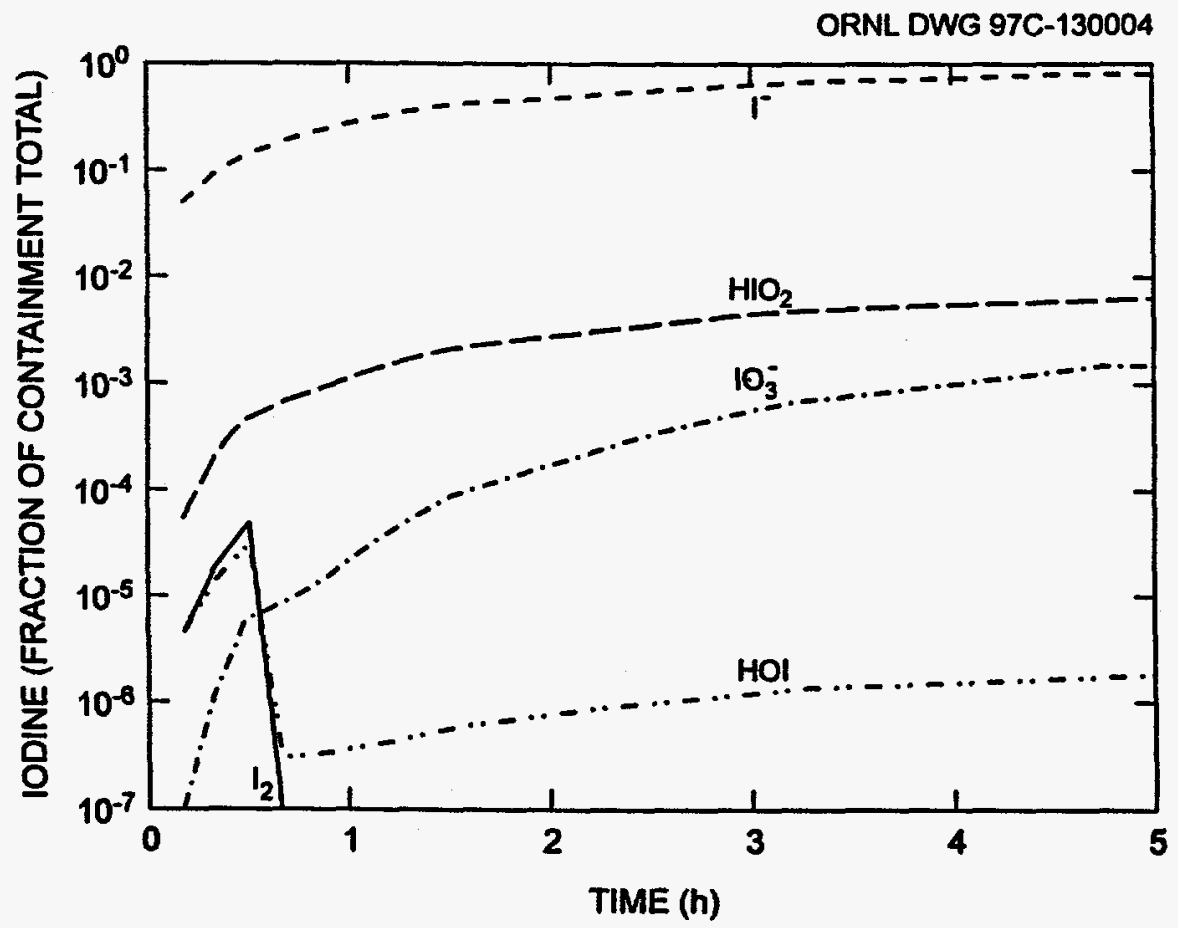

Figure 5.2 Aqueous iodine in containment water (Accident 2) 


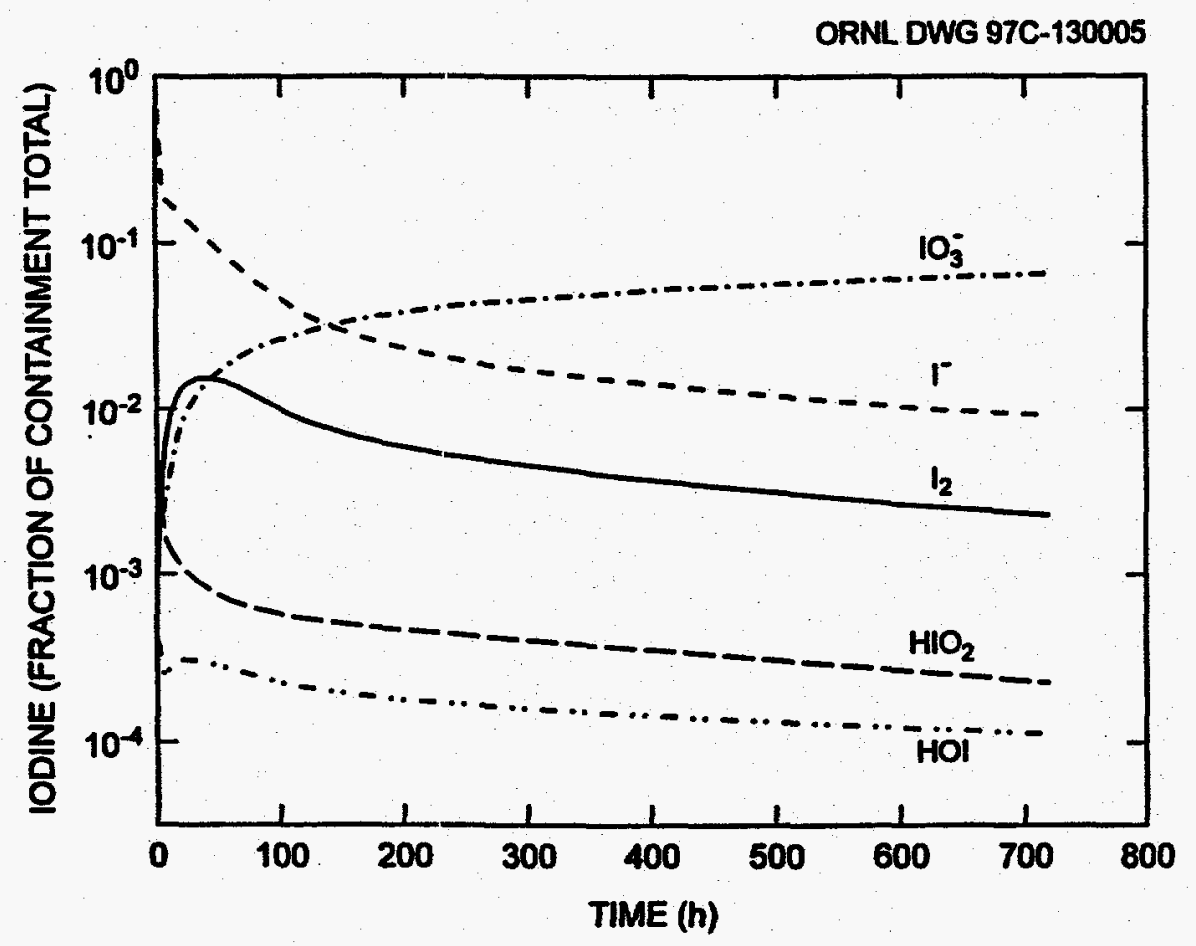

Figure 5.3 Aquieous iodine in the IRWST water (Accident 2)

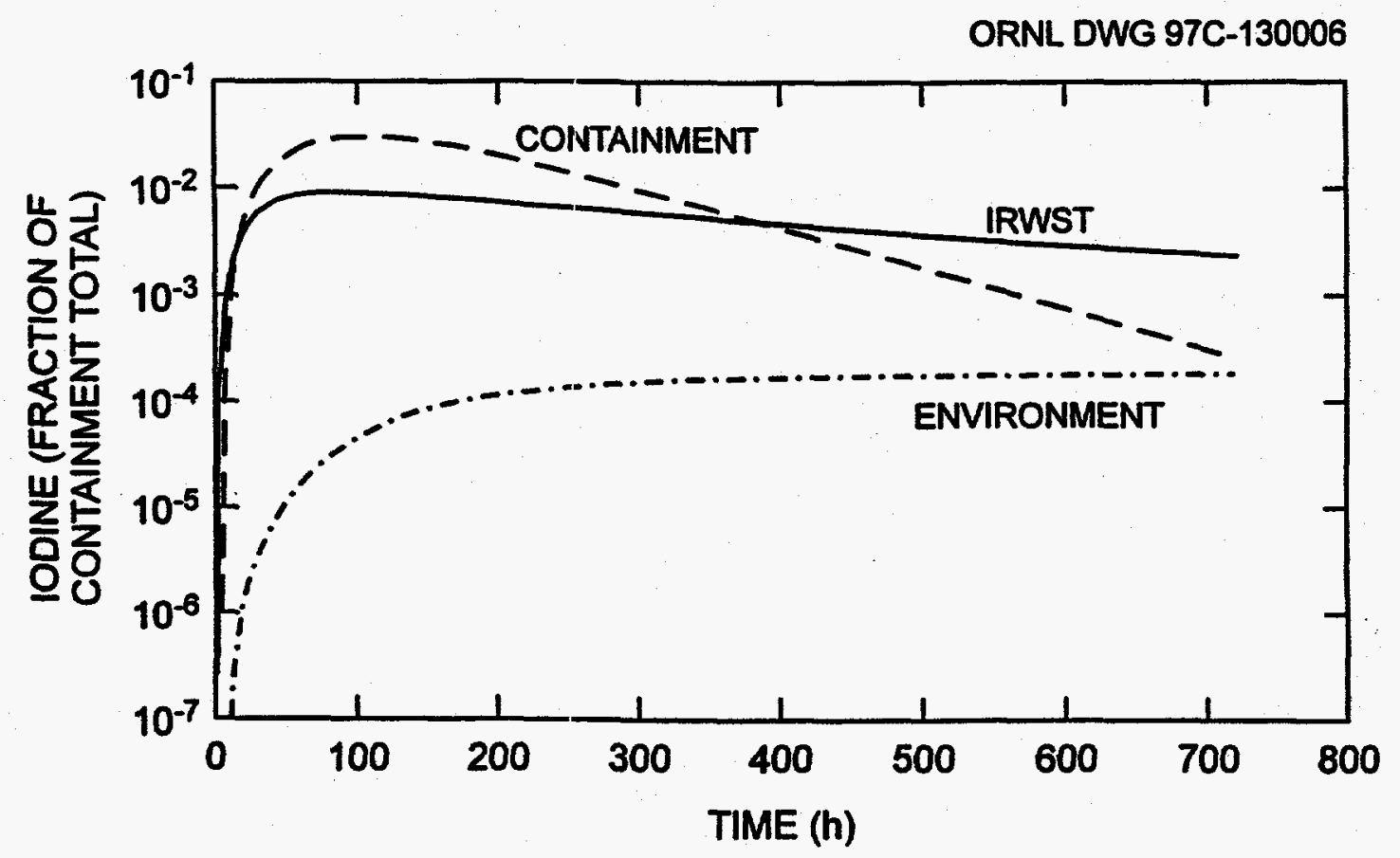

Figure 5.4 Total gas-phase iodine (Accident 2) 
Table 5.1 Cumulative environmental releases of iodine

\begin{tabular}{ccccccc}
\hline & \multicolumn{2}{c}{ Accident 2 } & & \multicolumn{2}{c}{ Accident 3 } \\
\cline { 2 - 5 } \cline { 5 - 6 } Time & $\mathrm{mol}$ & $\mathrm{Ci}$ & $\mathrm{mol}$ & $\mathrm{Ci}$ \\
\hline $\mathrm{h}$ & $10^{-8}$ & 0.013 & $10^{-12}$ & $10^{-5}$ \\
$8 \mathrm{~h}$ & $10^{-6}$ & 1.9 & $10^{-6}$ & 2 \\
$\mathrm{Id}$ & 0.00015 & 174 & 0.00022 & 245 \\
$4 \mathrm{~d}$ & 0.00500 & 3247 & 0.00770 & 4993 \\
$30 \mathrm{~d}$ & 0.02250 & 5981 & 0.03519 & 9326 \\
\hline
\end{tabular}

ORNL DWG 97C-130007

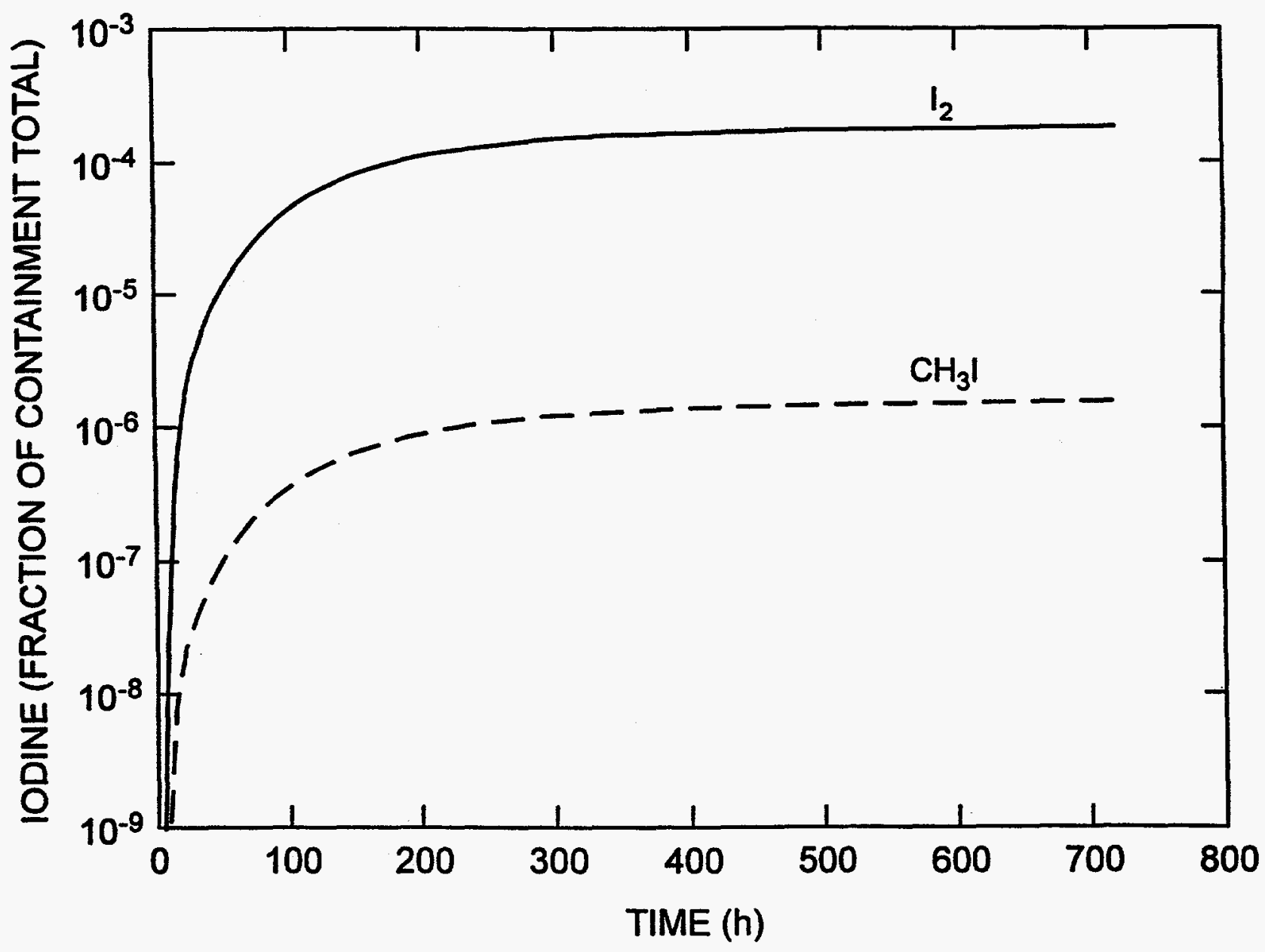

Figure 5.5 Environmental release for Accident 2 


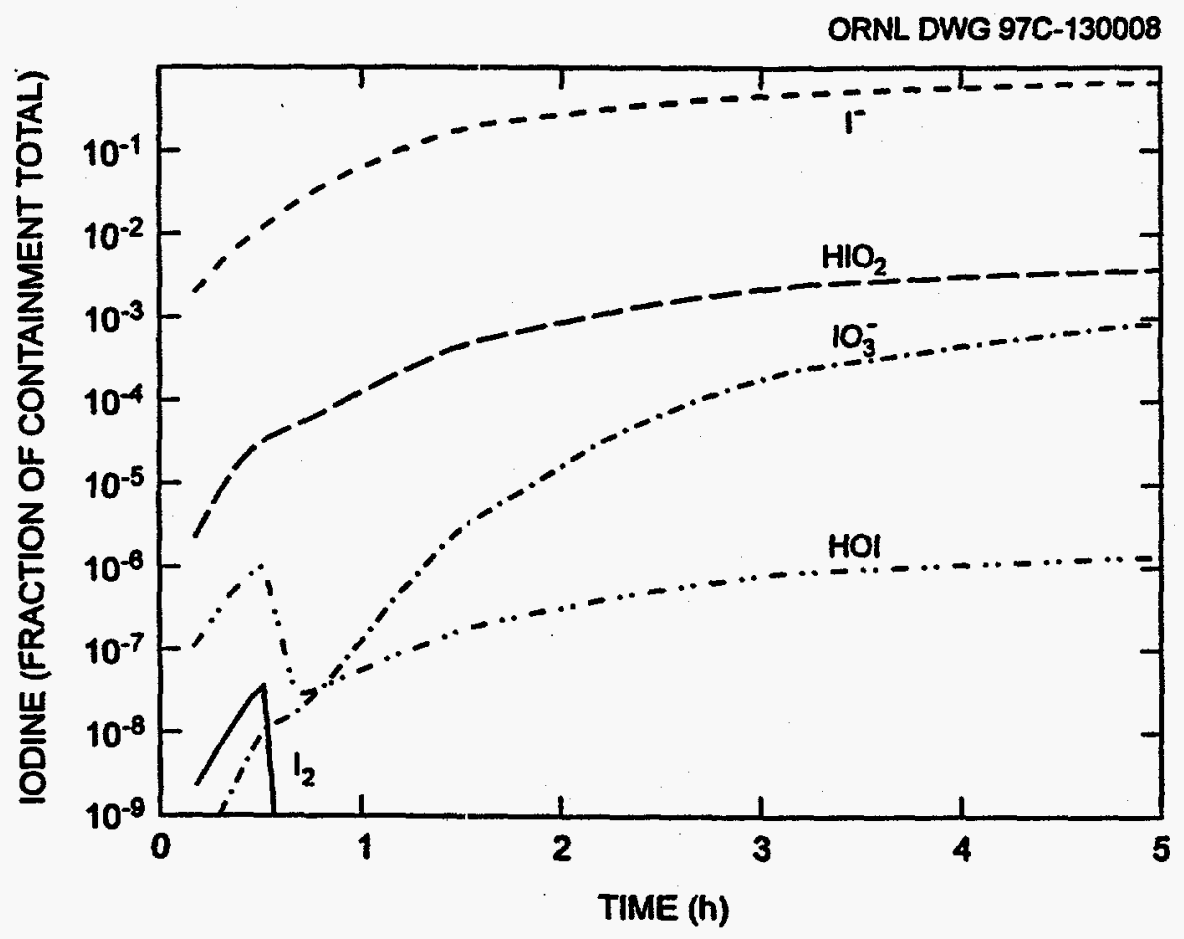

Figure 5.6 Aqueous iodine in principal containment (Accident 3)

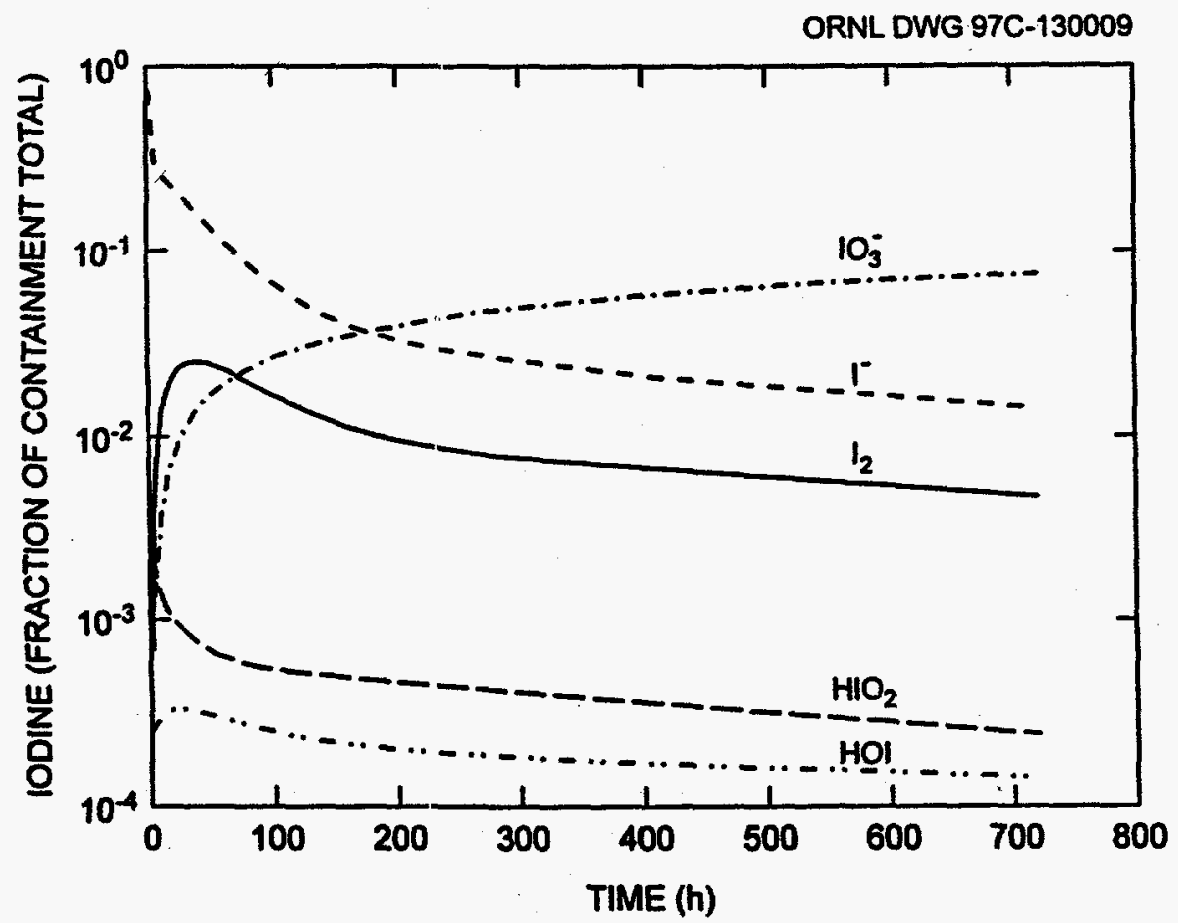

Figure 5.7 Aqueous iodine in the IRWST water (Accident 3) 
ORNL DWG 97C-130010

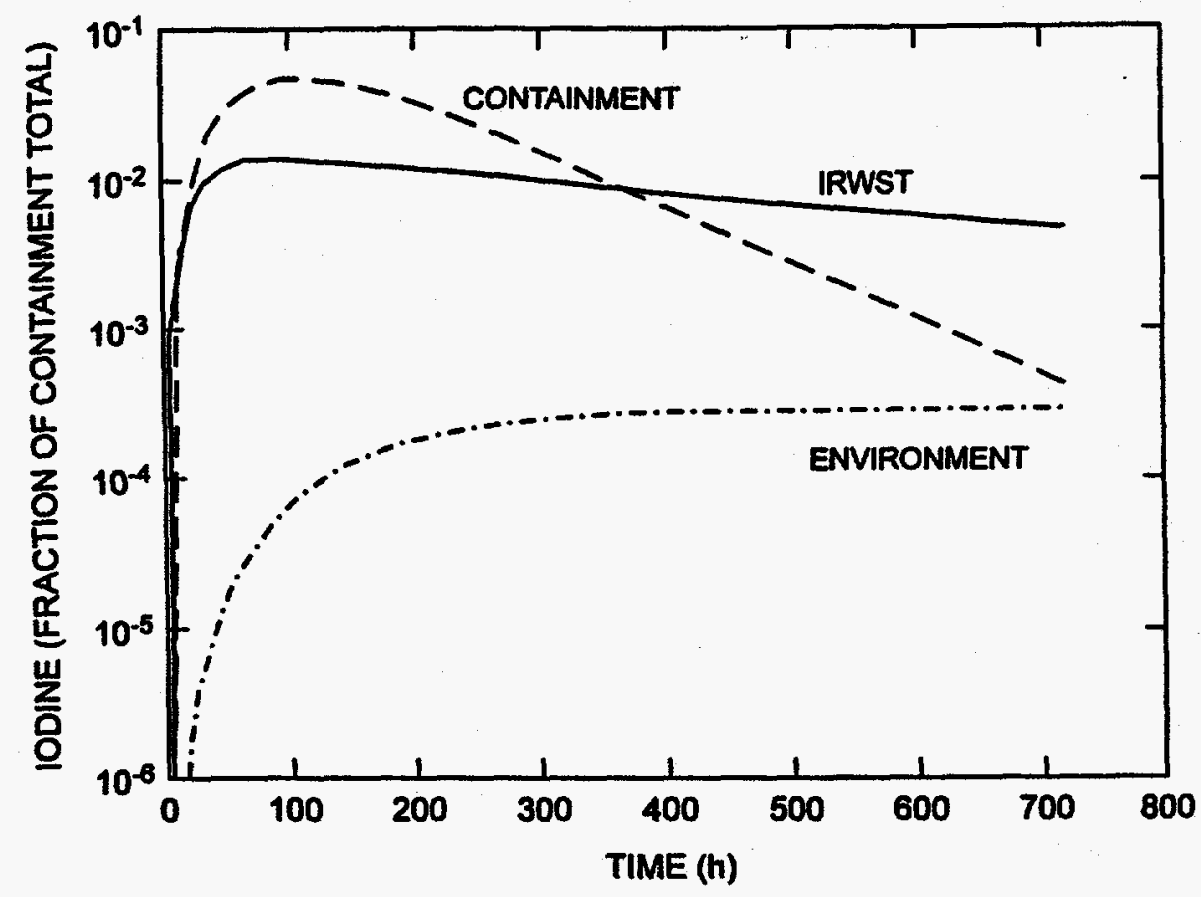

Figure 5.8 Total gas-phase iodine (Accident 3)

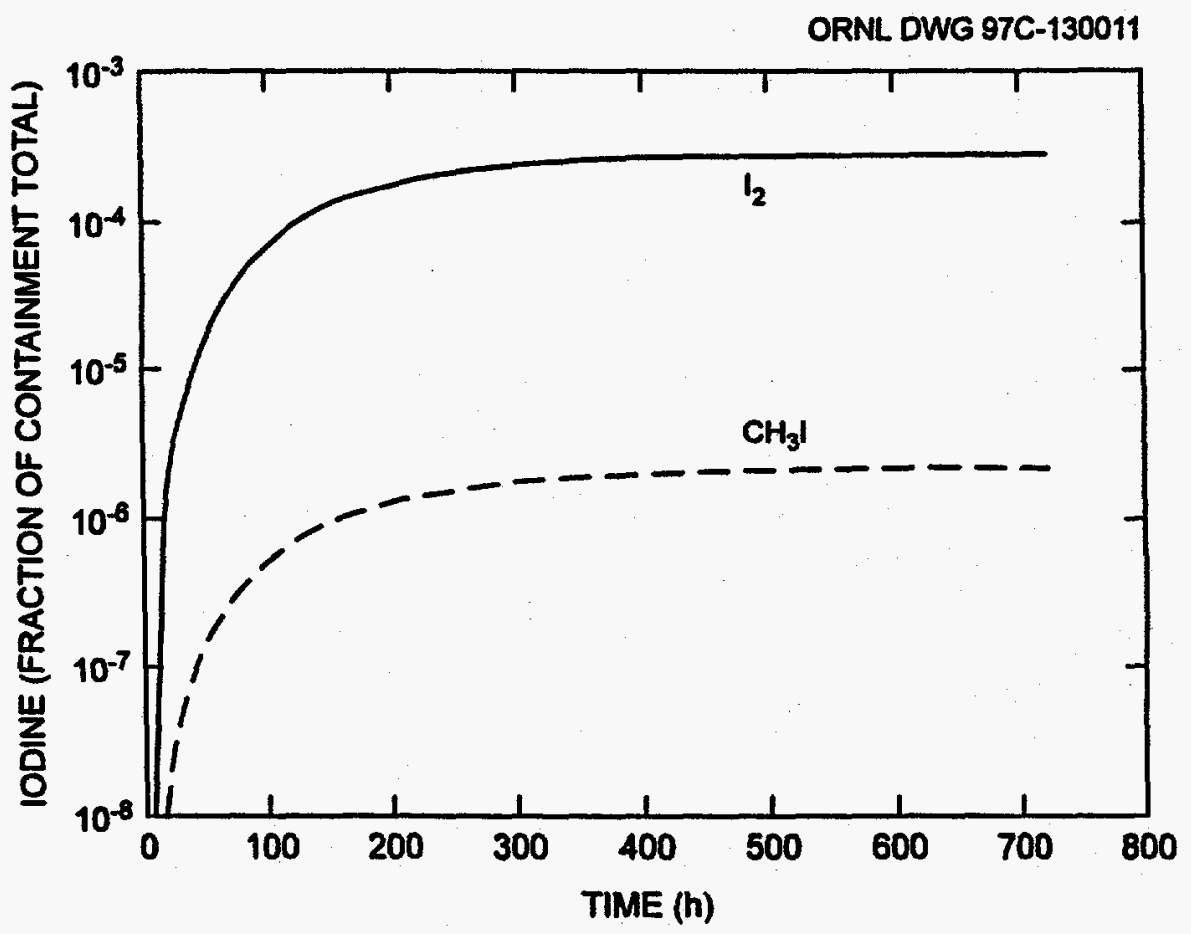

Figure 5.9 Environmental release (Accident 3) 


\section{Conclusions}

These accident sequences were formulated so as to bypass the $\mathrm{pH}$ control system in the AP-600 containment following a design-basis accident. Most iodine is eventually transported to the flooded containment, where TSP raises the pH to a level sufficiently high enough to prevent volatilization. However, a substantial fraction (about $20 \%$ in Accident 2 and $29 \%$ in Accident 3) of the iodine remains in the IRWST, which never fully drains. This water does not access the TSP; instead, it is the repository for acids produced by radiolysis in the containment. The continual lowering of $\mathrm{pH}$ in this volume leads to the production of some $\mathrm{I}_{2}$, which is vented to the containment airspace; a small amount is released to the environment.

It should be noted that no credit was taken for iodine deposition processes, which may remove some of the gaseous $\mathrm{I}_{2}$. In the IRWST, and to a lesser extent in the containment, the condensation of water on walls would (1) impede permanent deposition and (2) return $I_{2}$ to the IRWST pool. Here, it would be revolatilized and returned to the containment atmosphere, although the time lag would tend to lower the overall environmental source.

It should also be noted that the temperatures assumed for these accident sequences $\left(111-120^{\circ} \mathrm{C}\right)$ are beyond the range for which some of the models have been validated. The hydrolysis reactions have been measured at 25,50 , and $90^{\circ} \mathrm{C}$, and extrapolation to slightly higher temperatures is not unreasonable. Data for the radiolysis reactions are sparse at temperatures above $25^{\circ} \mathrm{C}$ and indicate that the model slightly overpredicts conversion to $I_{2}$ (which is conservative). ${ }^{11}$ The chemical equilibrium model is reliable at least to $100^{\circ} \mathrm{C}$, and slight extrapolation should be acceptable. The production of $\mathrm{HCl}$ is more pronounced at higher temperatures, although this effect is not significant below $150^{\circ} \mathrm{C}$. Thus, uncertainties due to temperature extrapolation are not large - and probably not nearly as great as uncertainties due to sequence formulation.

\section{References}

1. Beahm, E. C., C. F. Weber, and T. A. Dillow, "Technical Assistance in Review of Source Term Related Issues of Advanced Reactors," NUREG/CR-6408 (ORNL/TM-13144), draft, Oak Ridge National Laboratory, August 1998.

2. Soffer, L. et al., "Accident Source Terns for Light Water Nuclear Power Plants," NUREG-1465, February 1995.

3. Reference deleted.

4. Nuclear Regulatory Commission AP-600 documentation (FAX) to ORNL, October 30, 1996.

5. Regulatory Guide 1.4, "Assumptions Used for Evaluating the Potential Radiological Consequences of a Loss of Coolant Accident for Pressurized Water Reactors," June 1974.

6. Beahm, E. C. et al., "Iodine Chemical Forms in LWR Severe Accidents," NUREG/CR-5732 (ORNL/TM-11861), Oak Ridge National Laboratory, 1992.

7. Lin, C.-C., "Chemical Effects of Gamma Radiation on Iodine in Aqueous Solution," J. Inorg. Nucl. Chem. 42, $1101-7(1980)$.

8. Weber, C. F. et al., "Optimal Determination of Rate Coefficients in Multiple-Reaction Systems," Computers and Chem. 16(4), 325-33 (1992).

9. Mesmer, R. E. et al., "Acidity Measurements at Elevated Temperatures. VI. Boric Acid Equilibria," Inorg. Chem. 11(3), 537-43 (1972).

10. Beahm, E. C. et al., "Iodine Evolution and pH Control," NUREG/CR-5950 (ORNL/TM-12242), Oak Ridge National Laboratory, 1992. 


\section{References}

11. Weber, C. F. et al., "Models of Iodine Behavior in Reactor Containments," ORNL/TM-12202, Oak Ridge National Laboratory, October 1992.

12. Liebhafsky, H. A., "The Catalytic Decomposition of Hydrogen Peroxide by the Iodine-Iodide Couple at $25^{\circ} \mathrm{C}$," J. Amer. Chem. Soc. 54, 1792-1806 (1932).

13. Croff, A. G., "ORIGEN 2 - A Revised and Updated Version of the Oak Ridge Isotope Generation and Depletion Code," ORNL-5621, Oak Ridge National Laboratory, July 1980.

14. NUCDECAY - Nuclear Decay Data for Radiation Dosimetry, Calculations for ICRP and MIRD, DLC-172, Radiation Shielding Information Center, Oak Ridge National Laboratory, May 1995. See also K. F. Eckerman et al., "Nuclear Decay Data Files of the Dosimetry Research Group," ORNL/TM-12350, Oak Ridge National Laboratory, 1993, and K. F. Eckerman et al., Health Phys. 67(4), 338-45 (1994).

15. Eriksson, G., "Thermodynamic Studies of High-Temperature Equilibria. XII. SOL-GASMIX, A Computer Program for Calculation of Equilibrium Compositions in Multiphase Systems," Chemica Scripta 8, 3 (1975).

16. Hindmarsh, A. C., "ODEPACK, A Systematized Collection of ODE Solvers," R. S. Stepleman et al., eds., Scientific Computing, pp. 55-64, North-Holland, Amsterdam (1983). 


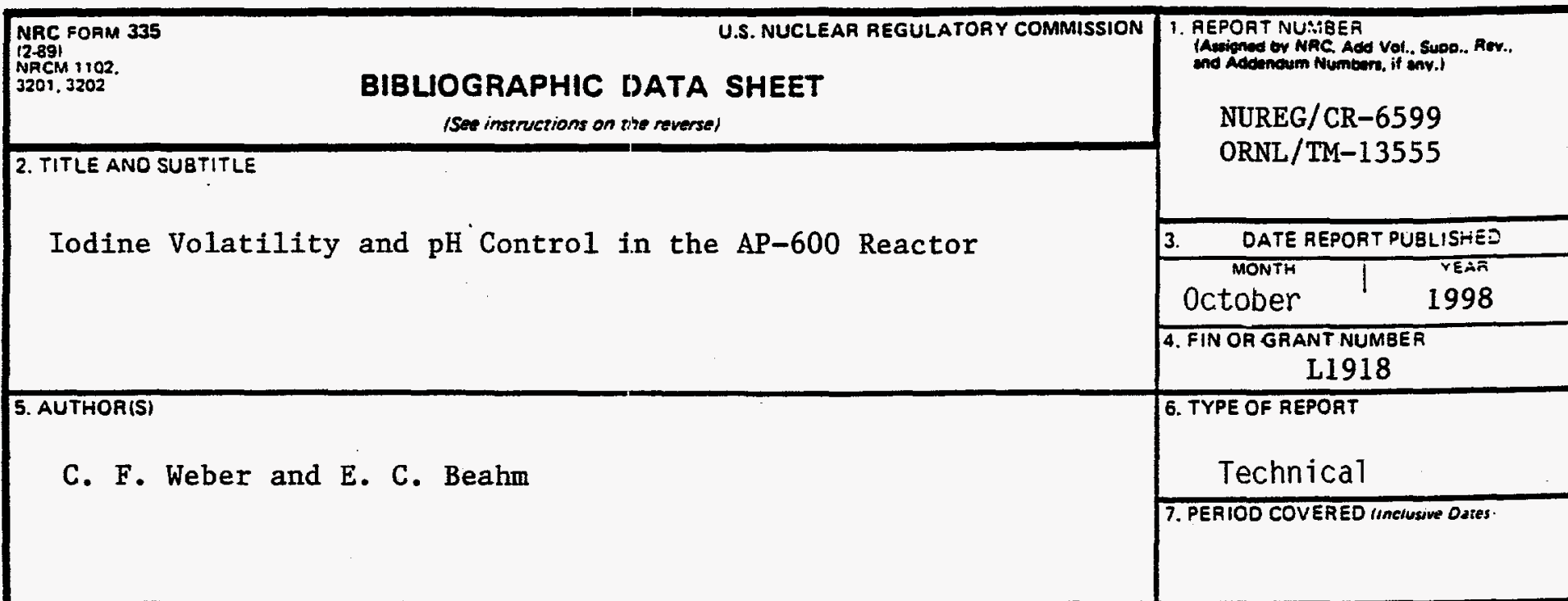

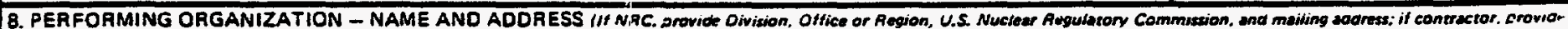
neme and meiling edoress,

Oak Ridge National Laboratory

Oak Ridge, TN 37831-5285

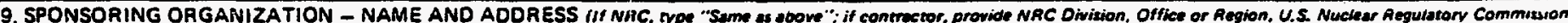
end mailing edareas.

Division of Reactor Program Management

Office of Nuclear Regulatory Research

U.S. Nuclear Regulatory Commission

Washington, D.C. 20555-0001

10. SUPPLEMENTARY NOTES

J.Y. Lee, NRC Project Manager

11. ABSTRACT 1200 wores or hess)

Two design-basis accidents for the AP-600 reactor are formulated and evaluated, in which significant bypass of the principal pH control system occurs. Some iodine released from the reactor primary system is retained in the Incontainment Refueling Water Storage Tank (IRWST) water, never entering the containment, where trisodium phosphate produces a high pH. Some of this iodine is volatjlized and is transported into the reactor containment. airspace. In the worst case, a small fraction is released to the environment at designbasis leak rate, yielding a total cumulative iodine release at 30 days of 0.0352 mol ( $0.023 \%$ of core iodine inventory) due to the iodine volatilization bypassing the pH control system. No fission product removal in the containment atmosphere (i.e., natural deposition sprays) is considered.

Iodine

Containment Water Pools

Unlimited

Fission Product Chemistry

$\mathrm{pH}$

pH Control Chemicals

Design Basis Accident

14. SECLAITY CLASSIFICATION
This Paget
Unclassified
This Regort
UnCl assified
15. NUMBER OF PAGES
16. PRICE

